Ittishal Educational Research Journal

July 2020, Vol. 1, No. 01, p. 1 - 12

http://journal.ittishal.net/index.php/ierj

DOI: 10.51425/ierj.v1i1.3

\title{
Critical Study on Arabic Learning by Non-Arabic Teachers and Employees Using Peer Learning in Assalaam Islamic Modern Boarding School
}

\author{
Pertapa Sari \\ Assalaam Islamic Modern Boarding School, Sukoharjo, Indonesia \\ hanpertapa@gmail.com
}

\begin{abstract}
Speaking using Arabic and English has become mandatory in Assalaam Islamic Modern Boarding School. The Arabic and English must be used in the daily activities around the boarding school. Therefore, all employees, both teachers and employees, are competing to learn these two foreign languages; Arabic and English. One method used by the employees and also teachers to learn Arabic in the Boarding school is by having a kind of course held in each unit or division. Teachers, especially non-Arabic teachers are also curious in learning Arabic. Meanwhile, employees who are non-Arabic based education also curious to learn Arabic. Those non-Arabic teachers and employees conduct the Arabic learning by taking around two hours course per week held in the middle of the break time. The tutor for the non-arabic teachers of course the Arabic teacher, means the tutor is their own friend. And the tutor for the employees is an arabic teacher also. And we call it peer learning which is using their own friend to be the tutor. Within one year academic 2017/2018, the Arabic course is taken and it gives a lot motivation to the non-Arabic teachers and also the employees. Peer learninng method used seemed to be the correct method in holding a course for the teachers and employees. And the study about it shows that by using this method, the Arabic can be easier to learn by nonArabic teachers and employees.
\end{abstract}

Keywords: Arabic learning; non-Arabic teachers and employees; peer learninng 


\section{INTRODUCTION}

Assalaam Islamic Modern Boarding School is one of Islamic Boarding School in Surakarta region. It has 2307 students in it, based on the year period 2018/2019 students data base, and 424 employees including the teachers and supporting employees. Assalaam Islamic Modern Boarding School try to concern on the use of two foreign languages usage in its daily activities, they are Arabic and English. That is why the use of Arabic and English become a mandatory in this boarding school. Therefore, those two languages, especially Arabic as the special identity of an Islamic institution become a language learned more by all society inside the boarding school. Since the Arabic is very common used by many teachers in the learning process in the class and also used by many students but some of the non-Arabic teachers and employees still cannot understand the language, it become something interesting to be observed in a research about the language learning. And this research held in the end year period of 2017/2018 through some groups of Arabic courses by non-Arabic teachers and employees.

A research about foreign language learning can have many directions. Some of those researches focus on syllabus, while others focus on new methods which become trend and others focus on the aim of the learning ${ }^{11 .}$ Talking about learning process, it will closely talk about teachers and students or the participants of the learning process.

Mostly, teachers understand that method is no longer become a crucial thing in a learning precess. Even some of them raise an opinion that the learning process now transform into two things, they are the development of socio-cultural aspect and the development of technology usage. ${ }^{2}$

Moreover, we have to realize that recently, second language acquisition has become wider. There are around 162 problems considered as potential field to be

${ }^{1}$ Jack C. Richards (2013). Curriculum Approaches in Language Teaching: Forward, Central, and Backward Design. RELC Journal.44:5.p 5-33

${ }^{2}$ MinooAlemi. (2010). Pedagogical Innovation in Language Teaching Methodologies. Journal of Language Teaching and Research. Academy Publisher Manufactured in Finland. November.

Vol.1.No.6 p.765-770 
studied. Books which discuss about the second language mastery contain more than 2000 pages and 70 chapters to be read by the readers. There are many things related to the Second Language mastery fro A to Z. This makes Foreign Language Learning become a rich project of research. ${ }^{3}$ Many researches done with the topic of second language aqcuisition.

Research with this topic sounds interesting since many people want to master other langusge besides their mother tongue so that it can make them feel more confident.

In this era, people with the mastery of more than one language, means they master at least one foreign language, become a prestigious thing. They will feel more confident in facing the work world. They will feel more confident in doing many thing especially when they meet people from other countries. Whatever their field of working, when they master at least English or Arabic, it will become a plus value for them.

\section{The Aim of Study}

The writer choose Assalaam Islamic Modern Boarding School as her object of the research because it is an interesting thing to observe and make a research on the use of Arabic in daily activities used by the non-Arabic teachers and employees.

The Arabic which is a language that must be used other than Indonesian or English, should be mastered by all society inside the boarding school. And those who cannot speak or write Arabic yet, usually study the Arabic with their peer.

Based on this background of study, this research wants to answer a question about the Arabic learning using peer learning for non-Arabic teachers and employees in Assalaam Islamic Modern Boardon School

\section{DISCUSSION AND THE RESULT}

We need to realize that the second language mastery is a long process, and this thing cannot be segmentated into levels. Even the process should be done from

${ }^{3}$ H. Douglas Brown (2007). Prinsip Pembelajaran dan Pengajaran Bahasa. Edisi Kedua. Pearson Education, Inc. Pg.X 
the kindergarten level to university level.4 And of course the long process of study needs detail and measured plan. That is why the Arabic teachers of course are the most hoped to make rhe Arabic learning become good day to day. We also understand that it is understandable when a teacher or tutor of language (Arabic) learning find one or two of the students succeed in their learning while others are not. This is how it become clearer in Foreign language learning that sometimes there is a wider space between both types of students. 5

In the beginning of 20th century, there is a boarding school of Islam used the theory of behaviorism and teach the Arabic inductively through the direct practice. 6

While in the modern boarding schoolthe Arabic learning is not only tought in the method of speech and translating, but also tought in the class using the more modern system of learning, such as using new books, doing spoken and written test, and also use the language as the daily language.

This research which is done in Assalaam Islamic Modern Boarding School observed the group of Arabic learning done by the non-Arabic teachers and employees. The non-Arabic teachers and employees, although they don't have the Arabic study background, but they curious and have more energy and spirit to study this language. During the period of year 2017/2018, there are two groups of Arabic course done by general division employees and one group of non-Arabic teachers. This three group then followed by other groups of teachers and employees from ther divisions. And by observing those groups of rabic courses, this article could be done well. The non-Arabic teachers here represent the number of $50 \%$ teachers of non-Arabic subject. While the employees group represent the numbr of all employees in Assalaam Islamic Modern Boarding School.

${ }^{4}$ Carol Swinney \& Diane Denoon. (2000). Curricular Standards for Foreign Language. Kansas: Kansas State Board of Educaton. Pg. 5

${ }^{5}$ Takayoshi Fujiwara. (2012). Beliefs about Language Learning of Thai Students Learning chinese and Japanese: Relationship with Past Learning Experiences and Target Language Variations.Electronic Journal of Foreign Language Teaching. Center for Lannguage Studies. Singapore: National University of Singapore. Vol 9. N0. 2. pp 170-182

${ }^{6}$ Jane K. Lartec, Anastacia M.Belisario, and friends. (2014). Strategies and Problems Encountered by Teachers in Implementing Mother Tongue - Based Instruction in Multilingual Classroom.. The IAFOR Journal of Language Learning. Volume 1. Issue I 
Table 1

Data taken from the HRD document year 2018/2019 about the number of the employees in Assalaam Boardinng School

\begin{tabular}{|c|l|c|}
\hline \multirow{2}{*}{ NO } & \multicolumn{1}{|c|}{ UNIT } & Total \\
\cline { 3 - 4 } & & \\
\hline \hline 1 & Directorate & 4 \\
\hline 2 & Secretariat & 13 \\
\hline 3 & Male Students Official & 33 \\
\hline 4 & Female Students Official & 27 \\
\hline 5 & Finance & 8 \\
\hline 6 & Quality Guarantee Uni & 4 \\
\hline 7 & MA/TKS & 7 \\
\hline 8 & MTS & 10 \\
\hline 9 & Board Of Kyai & 3 \\
\hline 10 & Library And Laboratory & 17 \\
\hline 11 & Astronomy & 3 \\
\hline 12 & Restaurant & 56 \\
\hline 13 & HRD & 17 \\
\hline 14 & Senior High School & 7 \\
\hline 15 & Vocational School & 6 \\
\hline 16 & General Unit & 68 \\
\hline 17 & Teachers & 141 \\
\hline & TOTAL & \\
\hline
\end{tabular}

\begin{tabular}{|c|c|}
\hline \multicolumn{2}{|c|}{ SEX } \\
\hline M & F \\
\hline 4 & 0 \\
\hline 12 & 2 \\
\hline 33 & 0 \\
\hline 0 & 27 \\
\hline 4 & 4 \\
\hline 1 & 3 \\
\hline 5 & 2 \\
\hline 7 & 3 \\
\hline 3 & 0 \\
\hline 11 & 6 \\
\hline 3 & 0 \\
\hline 22 & 34 \\
\hline 6 & 11 \\
\hline 4 & 3 \\
\hline 5 & 1 \\
\hline 66 & 0 \\
\hline 70 & 71 \\
\hline 256 & 167 \\
\hline
\end{tabular}

\section{Culture and Value}


For Assalaam Islamic Modern Boarding School as an academic institution which wants to keep exist and become apart in developing the changing of world, so that all students who are tought in this boarding school should be excellent people whoa are curious to get new knowledge so that they can exist in this global era, so do the teachers.

Islamic boarding school is a form of traditional education that pure come from Indonesian culture. In Islamic boarding school there are also values which give the soul that become the characteristics of it. There are the characteristic of respect others, doing everything together (togetherness), give honor to others, and so on. Besides those characteristics, in Islamic boarding school also known a principal called five souls of boarding school. Those are the sincerity, simplicity or modesty, brotherhood, autonomous, and free soul. ${ }^{7}$

All of those values should be preserved, developed, and should become the culture and value system which colour all people or society in the boarding school. One way that is effective to develop the value system and the five souls of boarding school is by modelling system. Means, the culture and value system will develop effectively when there is a oncrete model or sample. A concrete model here of course coming from the teachers, Arabic and non-Arabic teachers who always support and the five souls of boarding school. Those values will always become the soul of their live especially in their boarding school life.

There is a concrete model that reallycan be seen by all people in the society of boarding scool especially for students. Students see their teachers, teachers see their leader or responsible person the the unit, and so on. Also in this boarding school, it needs a refreshment and review about the cuture and value system in it which should be preserved adn developed together among all the societies in the boarding school. As what Tagyong said (2001) that in a process of education to reach the vision and mission and also the aim of education is not only by depending on the curriculum or the education program buat also determined by various factors or

${ }^{7}$ Elly Damaiwati. (2015). Kajian Kritis Tentang Pembinaan Santri yang Berorientasi pada Prestasi yang Unggul dan Kompetitif. Journal Ilmiah Pesantren. Volume 1. No.1. p.43 
multitude factors. Thus, learning models that are oriented towards superior human resources must always be strived and always be free from culture and value systems.

\section{Teachers and employees as the main part in succeeding the language program}

Boarding schools have urgent needs for superior human resources. That is why the teacher in boarding school is central and very important for the formation of reliable human resources. Because the teacher is a key factor in the learning process, that is why the performance of the teachers will determine the success of the learning process.

Assalaam Islamic Modern Boarding School has excellent programs, namely language activities, which prioritize the use of Arabic and English. The use of Arabic especially becomes more attention for non-Arabic teachers and employees because it is a characteristic of the boarding school. Because teachers and employees are adults in a boarding school environment, they automatically become examples for students. Automatically, with the excellent Arabic language program, the teachers and employees automatically become role models in the implementation of this language program. They are spearheading the implementation of this program. So that inevitably the teachers and employees must be able to use Arabic in daily life in a boarding school environment. ${ }^{8}$

According to Tilaar (2000) that at least the teacher figure should (1) have a mature and developing personality, (2) have a strong mastery of knowledge, (3) have the skills to arouse the spirit of learning for his students, and (4) develop potential continuously. Profession as a teacher is a profession that helps and guides human development. Therefore, the personality of a teacher must be a mature and constantly developing personality. Humans are blessed with different talents. But as a teacher is an absolute requirement to have a mature personality and vision that will be able to be an example for his students. The teacher plays an important and strategic role in the effort to shape the character of the nation through the development of the desired values.

\footnotetext{
${ }^{8}$ ibid
} 
Allah in the letter Ali Imran verse 79 reminds us "let us be the humans who are Rabbani namely humans who always learn and teach". It means that even if you are a teacher, you should never stop learning. The qualified teacher is a teacher who never stops learning, because by never stopping learning, he can inspire others.

Thus even though as a teacher, teachers in Assalaam boarding schools who feel that they cannot speak Arabic are also moved to learn Arabic. Especially in this boarding school they are expected to be the vanguard in the success of the language program. Thus, they also learn and learn without shame, especially to enrich their knowledge in Arabic.

Likewise the employees who work in the Assalaam boarding school environment are supporting staff for the success of all programs in boarding school, especially this language program. So they also have to be able to practice Arabic in daily life. Especially when they are working or working hours at boarding school. During working hours at boarding school, of course these employees will also be seen by all students. So they will play the same role with the teachers as models and examples for students. So that when these employees cannot speak Arabic, they also have to learn to be able to speak Arabic.

In other words, teachers and employees are a major part and play an important role in the success of the language program in Assalaam boarding school. Success or failure of a language program in Assalaam boarding school will depend on the support of teachers and employees. If these teachers and employees are able to carry out the language program well by practicing it in their daily work environment, then it will be able to become a benchmark for the success of the language program. Because the teachers and employees are the two main components in addition to students who are residents in Assalaam boarding school.

\section{Peer learning as method used in doing Arabic learning by the non-Arabic teachers and employees}

In the success of the language program in the Assalaam boarding school, teachers and employees who do not speak Arabic take the initiative to take Arabic courses. This course is carried out in teams or in groups that they organize 
themselves. One method they use is peer learning. What exactly is meant by peer learning?

Many institutions of learning now promote instructional methods involving 'active' learning that present opportunities for students to formulate their own questions, discuss issues, explain their viewpoints, and engage in cooperative learning by working in teams on problems and projects. 'Peer learning' is a form of cooperative learning that enhances the value of student-student interaction and results in various advantageous learning outcomes. To realize the benefits of peer learning, teachers must provide 'intellectual scaffolding'. Thus, teachers prime students by selecting discussion topics that all students are likely to have some relevant knowledge of; they also raise questions/issues that prompt students towards more sophisticated levels of thinking. In addition, collaborative processes are devised to get all group members to participate meaningfully.

For peer learning to be effective, the teacher must ensure that the entire group experiences "positive interdependence", face-to-face interaction, group processing and individual and group accountability. Positive interdependence emphasizes the importance and uniqueness of each group, while efforts are important while important cognitive activities and interpersonal dynamics are quiet at work. As students communicate with one another, they inferably assume leadership roles, acquire conflict-managing skills, discuss and clarify concepts, and unravel the complexities of human relationships within a given context; this process enhances their learning outcomes. Thus, students' learning extends far beyond the written word and even the given task. ${ }^{9}$

However, peer learning may encourage the presence of a freeloaders '- the team members who fail to fulfill their team responsibilities, but are given assignments or presentations of the same level as their more responsible teammates. Freeloading may be minimized by individual members of team members, or conducting a "post-test". There will then be two levels of accountability: the

${ }^{9}$ Felder, R.M. 'Active and Cooperative Learning'.

http://www2.ncsu.edu/unity/lockers/users/f/felder/public/Cooperative_Learning.html (last accessed: 20 August 2018). 
individual and the group. This method usually take the tutor from the same age as the member or the participants of the group so that they can feel mor comfortable and do not feel ashame if they make mistake while practicing.

This is what turned out to be the key to the success of the Arabic-language program in the Assalaam boarding school. Using the peer learning method, nonArabic teachers and employees do not feel shy and make them easier to learn Arabic.

To facilitate successful peer learning, teachers may choose from an array of strategies. They are (1) Buzz Groups: A large group of students is subdivided into smaller groups of 4-5 students to consider the issues surrounding a problem. After about 20 minutes of discussion, one member of each sub-group presents the findings of the sub-group to the whole group; (2) Affinity Groups: Groups of 4-5 students are each assigned particular tasks to work on outside of formal contact time. At the next formal meeting with the teacher, the sub-group, or a group representative, presents the sub-group's findings to the whole tutorial group; (3) Solution and Critic Groups: One sub-group is assigned a discussion topic for a tutorial and the other groups constitute 'critics' who observe, offer comments and evaluate the sub-group's presentation; and (4)'Teach-Write-Discuss': At the end of a unit of instruction, students have to answer short questions and justify their answers. After working on the questions individually, students compare their answers with each other's. A whole-class discussion subsequently examines the array of answers that still seem justifiable and the reasons for their validity. ${ }^{10}$

These strategies can be done in the application of peer learning which is conducted in groups and these will make the group more life and interesting to be done. The knowledge of language and the practicing of the Arabic as what the boarding school wants can be reached as well. By doing the peer learning, the Arabic learning seems to be easier to be done. If they want to ask because they don't understand yet, or if they make some mistakes in pronouncing or in writing, they will feel freely to ask without feeling shy. These strategies also make the course interesting and alive. They are considered as the best way to do practicing and

10 ibid 
studying language program which needs more attractive activities because language is a matter of practicing skill.

\section{CONCLUSION}

Teachers and employees in Assalaam boarding school are important and important components that must uphold the culture of boarding school and the noble values contained in it. They must be able to become mature and strong characters. The value system that has existed since the establishment of traditional boarding schools must always be maintained and developed so that it is able to become a characteristic that can be seeded until the end of time.

Teachers and employees at Assalaam boarding school are important and key components in the implementation of language programs there. So they will be the role models and examples for all students in it too. The implementation of language courses by non-Arabic teachers and employees using the peer learning method turned out to be very appropriate to the conditions in the field. this certainly facilitates the implementation of language programs and supports their success. 


\section{REFERENCES}

Brown. H. D. (2007). Prinsip pembelajaran dan pengajaran bahasa (2nd Ed). Pearson Education, Inc.

Damaiwati, E. (2015). Kajian kritis tentang pembinaan santri yang berorientasi pada prestasi yang unggul dan kompetitif. Journal Ilmiah Pesantren. Volume 1. No.1.

Felder, R.M. Active and cooperative learning. Retrieved http://www2.ncsu.edu/unity/lockers/users/f/felder/public/Cooperative_ Learning.html , 20 August 2018.

Fujiwara, T. (2012). Beliefs about Language Learning of Thai Students Learning chinese and Japanese: Relationship with Past Learning Experiences and Target Language Variations. Electronic Journal of Foreign Language Teaching. Center for Language Studies. Singapore: National University of Singapore. Vol 9, No. 2.

Lartec, J. K. \& Belisario, A.M. (2014). Strategies and problems encountered by teachers in implementing mother tongue - based instruction in multilingual classroom. The IAFOR Journal of Language Learning. Volume 1, Issue I.

MinooAlemi. (2010). Pedagogical innovation in language teaching methodologies. Journal of Language Teaching and Research. Academy Publisher Manufactured in Finland. November. Vol.1, No.6.

Richards, J.R. (2013). Curriculum approaches in language teaching: forward, central, and backward design. RELC Journal. 44:5. 
Swinney, C. \& Denoon, D. (2000). Curricular standards for foreign language. Kansas: Kansas State Board of Educaton.

Tagyong, Agus F. (2001). Pendidikan nasional dalam konteks perubahan ke arah masa depan. suatu gagasan. Makalah Seminar Reformasi Pendidikan Nasional.

Tilaar, HAR. (2001). Agenda reformasi pendidikan nasional. Jakarta: Tera Indonesia. 